ESCOBAR, Javier. "Faz objetiva del delito de sustracción de menores".

Polít. crim. Vol. 10, No 20 (Diciembre 2015), Art. 2, pp. 468-497.

[http://www.politicacriminal.cl/Vol_10/n_20/Vol10N20A2.pdf]

\title{
Faz objetiva del delito de sustracción de menores*
}

\section{Objective phase of the crime of child abduction}

\author{
Javier Escobar Veas \\ Magister en Derecho Penal y Procesal Penal \\ Profesor Auxiliar de Derecho Penal, Universidad Diego Portales \\ javier.escobar@mail.udp.cl
}

\section{Resumen}

Este artículo estudia la faz objetiva del delito de sustracción de menores, prescrito en el artículo 142 del Código Penal, el cual, según nuestra opinión, no ha recibido suficiente atención por parte de nuestra doctrina ni jurisprudencia. Lo anterior merece ser atendido y resuelto, toda vez que el delito en cuestión fue recogido en los últimos dos proyectos de nuevo Código Penal. En el primer capítulo, se describe el estado actual de la discusión y el aparente consenso en torno al delito en estudio. Luego, en un segundo capítulo, se criticarán ciertos puntos de este consenso, planteando algunos casos problemáticos. Finalmente, en el tercer y último capítulo, se propone una nueva interpretación de la faz objetiva del ilícito en estudio, reconociendo los aspectos positivos del actual consenso interpretativo, y modificando aquellos que fueron criticados.

Palabras clave: Sustracción de menores, libertad ambulatoria, seguridad individual.

\begin{abstract}
This paper studies the objective aspect of the crime of child abduction, prescribed in the article 142 of Criminal Code, which, in our opinion, hasn't received proper attention from our doctrine and courts. This should be analyzed and resolved, given that the crime was recognized in the last two projects of new Criminal Code. In the first chapter, it describes the actual state of discussion and the apparent consensus about the crime. After, in a second chapter, we will criticize some things of this consensus, propounding a few problematic cases. Finally, in the third chapter, it proposes a new interpretation of the objective aspect of the felony, taking the positive elements of the actual interpretative consensus, but changing those that were criticized.
\end{abstract}

Key words: Child abduction, freedom of movement, individual security.

\section{Introducción.}

Escribir un trabajo monográfico sobre el delito de sustracción de menores es una tarea que vale la pena intentar. Ello por cuanto, hasta el día de hoy, el ilícito mencionado no ha

\footnotetext{
* Agradezco sinceramente los valiosos comentarios y críticas del Prof. Héctor Hernández.
} 
ESCOBAR, Javier. "Faz objetiva del delito de sustracción de menores".

recibido la suficiente atención. Sin temor a exagerar, es posible sostener que los autores nacionales no le dedican más de siete páginas en sus manuales, y la ausencia de monografías es patente.

La tarea que nos hemos encomendado es contribuir al esclarecimiento de la faz objetiva del delito in comento, para así poder aportar a la discusión dogmática que se desarrolla hoy y que se desarrollará en el futuro. Si consideramos que el delito en estudio protege bienes jurídicos importantísimos, como se verá más adelante, y la pena asignada a su hipótesis básica es una de las más altas del Código -presidio mayor en sus grados medio a máximo-, su delimitación respecto de otros tipos penales no resulta baladí. Una pena tan elevada no puede quedar sometida al arbitrio o a la incertidumbre, ya que ello traicionaría la misión de la dogmática, cual es, generar certeza en la aplicación del derecho.

El presente trabajo se divide en tres capítulos, claramente identificables y con un propósito propio. El primero de ellos tiene por objeto repasar las opiniones doctrinarias y jurisprudenciales que se han esgrimido en torno al delito de sustracción de menores, explicarlas y complementarlas cuando sea necesario. El objetivo de este primer capítulo es, entonces, descriptivo. Los asuntos tratados serán: análisis histórico del artículo 142 del Código Penal ${ }^{1}$, para luego abordar el bien jurídico tutelado, la acción típica, el sujeto activo, el sujeto pasivo y la atenuante especial del artículo 142 bis.

El segundo capítulo representa, en cambio, un juicio crítico, y contiene nuestras opiniones personales y la contribución que, estimamos, estamos en condiciones de realizar. El primer apartado de dicho capítulo tratará la relación existente entre los bienes jurídicos protegidos, la acción típica y el sujeto activo del delito. El segundo apartado abordará algunos casos concretos en los cuales no es aplicable el tipo penal de sustracción de menores, y propondremos la aplicación de otras figuras típicas. En el tercer apartado estudiaremos el tema que, desde nuestra perspectiva, ha recibido quizás la menor atención por parte de los autores nacionales, este es, los medios comisivos. A propósito de este punto trataremos primero la violencia o intimidación, para luego abordar el engaño, ya sea que se dirija contra el menor o contra la persona que lo tiene bajo su resguardo. En el cuarto y último apartado, analizaremos la relación existente entre el delito de sustracción de menores y otros tipos penales afines, especialmente aquellos atentatorios contra el estado civil de las personas.

El tercer capítulo constituye la conclusión de este trabajo. En ésta se sistematizarán los elementos positivos del actual consenso doctrinario y jurisprudencial, con aquellos puntos que se propone modificar, construyendo así una nueva interpretación de la faz objetiva del delito en análisis.

\footnotetext{
${ }^{1}$ Cuando señale algún artículo, sin expresar cuerpo legal, debe entenderse que me estoy refiriendo al Código Penal nacional.
} 
Polít. crim. Vol. 10, No 20 (Diciembre 2015), Art. 2, pp. 468-497.

[http://www.politicacriminal.cl/Vol_10/n_20/Vol10N20A2.pdf]

\section{Estado actual de la discusión.}

Como se señaló anteriormente, el presente capítulo tratará: Análisis histórico, bien jurídico protegido, acción típica, sujeto activo, sujeto pasivo, y la atenuante especial del artículo 142 bis.

El actual artículo 142 reza:

"La sustracción de un menor de 18 años será castigada:

1. Con presidio mayor en su grado máximo a presidio perpetuo, si se ejecutare para obtener un rescate, imponer exigencias, arrancar decisiones o si resultare un grave daño en la persona del menor.

2. Con presidio mayor en su grado medio a máximo en los demás casos².

Si con motivo u ocasión de la sustracción se cometiere alguno de los delitos indicados en el inciso final del artículo anterior, se aplicará la pena que en él se señala".

\subsection{Análisis histórico.}

En el Fuero Juzgo (Lib. VII, Título III, Ley $3^{\circ}$ ) se castigó el hecho de sustraer los hijos de los hombres libres de casa de sus padres. El culpable quedaba como siervo del hijo robado o debía pagar una pena pecuniaria ${ }^{3}$. El mismo hecho, incriminado conjuntamente con el robo de siervos, es sancionado en las Partidas (Partículo VII, Título XIV, ley 22) ${ }^{4}$.

El Código Penal Español de 1822 se refirió a este delito en su artículo 664, en los siguientes términos:

"El que por fraude o violencia robare o hiciere robar algún menor, o le sacare o separare, o hiciere sacar o separar del lugar en que estaba puesto por las personas bajo cuya autoridad o dirección estaba, o a quien había sido confiado, será castigado con la pena de reclusión".

El Código Penal Español de 1848 mantuvo el delito en estudio, pero introdujo modificaciones sustanciales. La más importante fue que limitó la edad del sujeto pasivo a siete años. El artículo 408 del cuerpo legal recién citado disponía:

"La sustracción de un menor de siete años será castigada con la pena de cadena temporal".

\footnotetext{
${ }^{2}$ Ésta es la hipótesis básica del delito de sustracción de menores.

${ }^{3}$ CUELLO, Eugenio, Derecho Penal, T. II, V. $2^{\circ}, 14^{a}$ Edición, Barcelona: Bosch Casa Editorial, 1982, p.750.

${ }^{4}$ CUELLO, Derecho Penal, cit. nota ${ }^{\circ} 2$, p. 750.

${ }^{5}$ PACHECO, Joaquín, El Código Penal Concordado y Comentado, reedición de la tercera edición de 1867, Madrid: Edisofer, 2000, p. 1164.

${ }^{6}$ PACHECO, El Código Penal, cit. nota n ${ }^{\circ}$ 5, p. 1163.
} 
ESCOBAR, Javier. "Faz objetiva del delito de sustracción de menores".

En Chile, según consta en las actas de la Comisión Redactora del Código Penal, el delito de sustracción de menores tiene su origen directo en el artículo 408 del Código Penal de España de 1848. En efecto, en la Sesión 31 del 21 de abril de 1871 se señaló:

"El artículo $127^{7}$ tomado del 408 del Código Español, fue aprobado después de una corta discusión, que tuvo por objeto señalar a este grave delito, atendidas las diversas circunstancias que pueden agravar o atenuar la criminalidad del hecho en cada caso, una mayor escala de penalidad, dejando su graduación a arbitrio del tribunal para la aplicación de la pena".

En la versión original del Código Penal, aprobada por el Congreso de la República en 1874, el artículo 142 disponía lo siguiente:

"La sustracción de un menor de diez años será castigada con presidio mayor en cualquiera de sus grados.

Si el sustraído fuere mayor de diez y menor de veinte años, la pena será presidio menor en cualquiera de sus grados".

Como se puede apreciar, el texto definitivo del delito en estudio distinguía si el menor sustraído era menor o mayor de diez años. Esta era una virtud legislativa que con el transcurso del tiempo se perdió, como se verá a continuación.

En el año 1950 se promulgó la ley $\mathrm{N}^{\circ}$ 9.762, que modificó de manera importante el texto del artículo 142. Esta modificación mantuvo la diferencia penológica que dependía de la edad de la víctima (si el sustraído era mayor o menor de diez años), pero introdujo diversas hipótesis calificantes y una atenuante especial. Esta última consistía en que si antes de iniciarse el procedimiento judicial, el raptor devolvía voluntariamente al menor sustraído, libre de todo daño, a sus padres, guardadores, encargados de su persona o a la autoridad, podía imponérsele una pena inferior en dos grados.

En los años $1983^{10}$ y $1993^{11}$ se modificó sucesivamente el artículo 142 , sobre todo en relación a las circunstancias calificantes y las penas a imponer. Este último año se eliminó la diferencia penológica dependiente de la edad de la víctima. Además, la atenuante especial se trasladó a un nuevo artículo 142 bis, con algunas modificaciones. El texto actual del artículo 142 bis es el siguiente:

"Si los partícipes en los delitos de secuestro de una persona o de sustracción de un menor, antes de cumplirse cualquiera de las condiciones exigidas por los secuestradores para devolver a la víctima, la devolvieren libre de todo daño, la pena asignada al delito se rebajará en dos grados. Si la devolución se realiza después de

\footnotetext{
${ }^{7}$ En un principio el delito de sustracción de menores se consagraría en el artículo 127, pero finalmente fue colocado en el artículo 142.

${ }^{8}$ Actas de las Sesiones de la Comisión Redactora del Código Penal de Chile.

${ }^{9}$ Actas de las Sesiones de la Comisión Redactora del Código Penal de Chile.

${ }^{10}$ Ley 18.222 .

${ }^{11}$ Ley 19.241 .
} 
Polít. crim. Vol. 10, No 20 (Diciembre 2015), Art. 2, pp. 468-497.

[http://www.politicacriminal.cl/Vol_10/n_20/Vol10N20A2.pdf]

cumplida alguna de las condiciones, el juez podrá rebajar la pena en un grado a la señalada en los dos artículos anteriores".

\subsection{Bien jurídico protegido.}

A diferencia del delito de secuestro, donde existe unanimidad en que el bien jurídico protegido es la libertad ambulatoria ${ }^{12}$, en el delito de sustracción de menores el tema es muy discutido. Aparentemente, respecto de lo único que habría consenso es sobre el carácter pluriofensivo del delito, es decir, se trataría de un ilícito que atentaría contra más de un bien jurídico. El epígrafe del párrafo donde está contenido el delito en estudio, al titularse "Crímenes y simples delitos contra la libertad y seguridad, cometidos por particulares", arroja algunas luces, pero una respuesta satisfactoria necesariamente exige una mayor reflexión. Sobre el punto, al menos pueden identificarse dos tradiciones jurídicas: Una que concibe este delito como un atentado contra la libertad del menor y su seguridad, y otra que lo concibe como un atentado contra los derechos tutelares de los padres o la familia.

Representantes de la primera postura son Alfredo Etcheberry, quien sostiene que

"la protección a la libertad ambulatoria aparece muy mezclada con la tutela de la seguridad del menor, y aun cuando se refiere a aquélla, la lesión se produce a veces a través de la particular forma que asume la libertad en estos casos, que es ejercida en lugar y a nombre del menor por aquellos a quienes el orden jurídico encomienda su cuidado y protección". 13

Sergio Politoff, Jean Pierre Matus y Cecilia Ramírez, a su vez, exponen que "entre nosotros en este delito lo que se quiere subrayar es que se afecta en forma directa la seguridad como presupuesto de la libertad en general, y en forma especial como presupuesto de la libertad ambulatoria del menor". ${ }^{14}$ Juan Bustos postula que "lo que se quiere recalcar en forma expresa es que se afecta directamente tanto la seguridad, como presupuesto de la libertad en general (...), pero, además, y de modo principal, la seguridad como presupuesto de la libertad ambulatoria". ${ }^{15}$ Gustavo Labatut, pese a no profundizar en el tópico, afirma categóricamente que "este delito constituye un gravísimo atentado contra la libertad personal". 16

Por último, Nurieldín Hermosilla concluye, en su monografía, que:

"El bien jurídico que se protege por la disposición del artículo 142 es la libertad del menor, pero entendida como un bien compuesto y complejo, que puede en

\footnotetext{
${ }^{12}$ ETCHEBERRY, Alfredo, Derecho Penal, T. III, $3^{\text {a }}$ Edición, Santiago: Editorial Jurídica de Chile, 1998, p. 201; POLITOFF, Sergio; MATUS, Jean Pierre; RAMÍREZ, María Cecilia, Lecciones de Derecho Penal Chileno, Parte Especial, $2^{a}$ Edición, Santiago: Editorial Jurídica de Chile, 2006, p. 201; GARRIDO, Mario, Derecho Penal, T. III, $4^{\text {a }}$ Edición, Santiago: Editorial Jurídica de Chile, 2005-2010, pp. 384 y 385.

${ }^{13}$ ETCHEBERRY, Derecho Penal, cit. nota ${ }^{\circ} 12$, p. 211.

${ }^{14}$ POLITOFF/MATUS/RAMÍREZ, Lecciones de Derecho Penal, cit. nota n ${ }^{\circ}$ 12, p. 211.

${ }^{15}$ BUSTOS, Juan, Manual de Derecho Penal, Parte Especial, 2a Edición, Barcelona: Ariel, 1991, p. 108.

${ }^{16}$ LABATUT, Gustavo, Derecho Penal, Parte Especial, V. II, $7^{\text {a }}$ Edición, Santiago: Editorial Jurídica de Chile, 1983, p. 33 y 34.
} 
ESCOBAR, Javier. "Faz objetiva del delito de sustracción de menores”.

determinados momentos mostrar facetas muy variadas, no consistentes precisamente en la libertad en la mayoría de los casos (...) es complejo, porque, por ejemplo, y a diferencia del secuestro, la libertad del menor se confunde, se integra en conceptos distintos al de la libertad, incluso en conceptos antagónicos. En la especie, hay que considerar la libertad como derechos y facultades que no ejerce el titular de ellos (el menor), sino otra persona por él, por mandato expreso de la ley (...). Por eso se funde la libertad del menor con su seguridad". 17

Ahora, como representantes de la segunda postura podemos considerar principalmente autores extranjeros. Manuel Cobo argumentó que, en el delito de sustracción de menores, se "protege, con rango de bien jurídico, la familia, concretada en los derechos y deberes inherentes a la patria potestad, tutela o mera guarda, o institución afín". ${ }^{18}$ Joaquín Pacheco señalaba que la sustracción de menores "es un delito de inmensa gravedad en sí propio, de inmensa perversidad en el que lo ejecuta". Afirmaba, asimismo, que la persona que se hubiese apoderado de un niño, sólo para encerrarlo y privarlo de su libertad, para luego devolverlo a salvo a sus padres, no responde por el delito de sustracción de menores, sino que conforme a las disposiciones que sancionan las detenciones ilegales ${ }^{19}$. De la opinión de Pacheco se deriva que lo que le otorgaría identidad al ilícito in comento sería el atentado contra los derechos tutelares y el estado civil del menor. En efecto, el autor afirma, más adelante, que la sustracción tiene como fin hacerle perder al niño las nociones de su origen, la posesión de su real y efectiva existencia ${ }^{20}$. Francisco Carrara, a su vez, incluyó el delito de sustracción de menores en el apartado de los "Delitos contra la Familia", entendiendo que el bien jurídico lesionado son los derechos y deberes inherentes a la patria potestad, y no la libertad personal del menor, ni siquiera su seguridad individual ${ }^{21}$. José Rodríguez Devesa concluyó, a propósito del estudio del sujeto activo, que lo fundamental en este delito es el menosprecio de la voluntad de aquel a quien está atribuida la custodia del menor, siendo éste el bien jurídico protegido ${ }^{22}$.

Francisco Muñoz Conde ${ }^{23}$ y Antonio Quintano Ripollés ${ }^{24}$, si bien estudian el delito a la luz de la legislación española, participan de la primera postura. En efecto, ambos sostienen que la sustracción de menores atenta contra la libertad en sentido amplio, aun cuando puedan afectarse otros bienes jurídicos de forma colateral. Así, este último autor expone que "al fin y al cabo el menor y aun el niño son personas, con esferas de libertad limitadas, sin duda, pero reales". En aquellos casos extremos en que el menor no pueda ejercerla, lo harán sus

${ }^{17}$ HERMOSILLA, Nurieldín, Sustracción de Menores. Ensayo de una interpretación dogmática del artículo 142, Memoria de Prueba para optar al grado académico de Licenciado en Ciencias Jurídicas y Sociales de la Universidad de Chile, Santiago: Editorial Universitaria, 1963, p. 11.

18 COBO, Manuel, "Consideraciones Técnico-Jurídicas sobre la Sustracción de Menores", Separata de Anuario de Derecho Penal y Ciencias Penales, Madrid: Instituto Nacional de Estudio Jurídicos, 1961, p. 229.

${ }^{19}$ PACHECO, El Código Penal, cit. nota n ${ }^{\circ}$ 5, p. 1165.

${ }^{20}$ PACHECO, El Código Penal, cit. nota n ${ }^{\circ}$ 5, p. 1165.

${ }^{21}$ CARRARA, Francesco, Programa de Derecho Criminal, Parte Especial, V. III, Buenos Aires: Editorial DePalma, 1978, pp. 447 y ss.

${ }^{22}$ RODRIGUEZ DEVESA, José, Derecho Penal Español, Parte Especial, $9^{a}$ Edición, Madrid: Artes Gráficas Carasa, 1983, p. 298.

${ }^{23}$ MUÑOZ CONDE, Francisco, Derecho Penal, Parte Especial, 5a Edición, Sevilla: Publicaciones de la Universidad de Sevilla, 1983, p. 140.

${ }^{24}$ QUINTANO RIPOLLÉS, Antonio, Tratado de la Parte Especial del Derecho Penal, T. I, V. II, $2^{\text {a }}$ Edición, Madrid: Editorial Revista de Derecho Privado, 1972, pp. 930 y 931. 
padres o guardadores en su nombre, de donde se deduce que hay un valor o interés de libertad, cambiando tan sólo su titularidad ${ }^{25}$.

Nuestra jurisprudencia también ha abordado el problema. El Tribunal de Juicio Oral en lo Penal de Antofagasta ha sostenido una postura mixta en dos sentencias. En causa Rit 962005 expresó que los bienes jurídicos protegidos en la sustracción de menores son la seguridad del menor y el derecho de quienes tienen su patria potestad o poder de control sobre el menor para mantenerlo dentro de su esfera de protección o cuidado. ${ }^{26} \mathrm{~A}$ su vez, en sentencia Rit 175-2009 señaló que los bienes jurídicos que el tipo penal protege son la seguridad de un menor, su libertad ambulatoria y los derechos de custodia de las personas que lo tienen a su cargo ${ }^{27}$.

El Tercer Tribunal de Juicio Oral en lo Penal de Santiago, en sentencia Rit 172-2007, también sostuvo una postura mixta, y expuso:

"Estos magistrados estiman que, en particular, se encuentran afectados por este ilícito tanto la libertad personal del menor (escuela alemana) como los derechos derivados en relación al niño (escuela española), dejando clara la existencia de una afectación también del ámbito de la seguridad tanto en lo que dice relación con la libertad general, como asimismo con la libertad ambulatoria". ${ }^{28}{ }_{-}^{29}$

De la doctrina y jurisprudencia citada podemos concluir que, si bien en la doctrina nacional la primera postura goza de amplia mayoría - por no decir unanimidad-, en la jurisprudencia se le ha dado un espacio de protección a los derechos tutelares y a las relaciones filiales, sin que se pueda concluir que la práctica forense adscriba mayoritariamente a la postura defendida por la doctrina, sino que todo lo contrario, pareciera que la tendencia es ir hacia una postura mixta, que reconoce como bienes jurídicos protegidos tanto la libertad del menor como su seguridad y los derechos tutelares.

\subsubsection{Excurso sobre la situación española.}

El Código Penal Español de 1973, con sus posteriores modificaciones, continuó la tradición de establecer un delito de sustracción de menores, idéntico -al menos en su núcleo- al que nosotros conocemos. En efecto, el artículo 484 de dicho cuerpo legal sancionaba la sustracción de un menor de siete años, sin más.

Esto cambió en 1995. El nuevo Código Penal Español, dictado ese año, derogó el delito en estudio, sin perjuicio de que se ha sostenido que el injusto continuó castigándose bajo otros títulos ${ }^{30}$.

\footnotetext{
${ }^{25}$ QUINTANO RIPOLLÉS, Tratado, cit. nota n² 24, pp. 930 y 931.

${ }^{26}$ Considerando Décimo Sexto.

${ }^{27}$ Considerando Noveno.

${ }^{28}$ Considerando Cuarto.

${ }^{29}$ En idéntico sentido se pronunció el Sexto Tribunal de Juicio Oral en lo Penal de Santiago, en sentencia Rit 120-2006, Considerando Décimo Cuarto.

${ }^{30}$ A este respecto ver CORTÉS, Emilio, Aspectos de los Delitos contra la Filiación y Nueva Regulación del Delito de Sustracción de Menores, Madrid: Instituto de Criminología, 1996, pp. 113 y ss.
} 
ESCOBAR, Javier. "Faz objetiva del delito de sustracción de menores".

Sin embargo, en el año 2002 la Ley Orgánica 9/2002 introdujo un nuevo artículo 225 bis, el cual estableció un delito de sustracción de menores, pero muy distinto al que anteriormente había existido ${ }^{31}$.

El actual artículo 225 bis del Código Penal Español reza de la siguiente forma:

"1. El progenitor que sin causa justificada para ello sustrajere a su hijo menor será castigado con la pena de prisión de dos a cuatro años e inhabilitación especial para el ejercicio del derecho de patria potestad por tiempo de cuatro a 10 años.

2. A los efectos de este artículo, se considera sustracción:

$1^{\circ}$ El traslado de un menor de su lugar de residencia sin consentimiento del progenitor con quien conviva habitualmente o de las personas o instituciones a las cuales estuviese confiada su guarda o custodia.

$2^{\circ}$ La retención de un menor incumpliendo gravemente el deber establecido por resolución judicial o administrativa.

3. Cuando el menor sea trasladado fuera de España o fuese exigida alguna condición para su restitución la pena señalada en el apartado 1 se impondrá en su mitad superior.

4. Cuando el sustractor haya comunicado el lugar de estancia al otro progenitor o a quien corresponda legalmente su cuidado dentro de las veinticuatro horas siguientes a la sustracción con el compromiso de devolución inmediata que efectivamente lleve a cabo, o la ausencia no hubiere sido superior a dicho plazo de veinticuatro horas, quedará exento de pena. Si la restitución la hiciere, sin la comunicación a que se refiere el párrafo anterior, dentro de los quince días siguientes a la sustracción, le será impuesta la pena de prisión de seis meses a dos años. Estos plazos se computarán desde la fecha de la denuncia de la sustracción.

5. Las penas señaladas en este artículo se impondrán igualmente a los ascendientes del menor y a los parientes del progenitor hasta el segundo grado de consanguinidad o afinidad que incurran en las conductas anteriormente descritas".

Como se puede apreciar de la simple lectura de la norma transcrita, el delito de sustracción de menores ha adquirido en España una fisionomía distinta a la que se conocía hasta ese momento. A modo de ejemplo, pueden citarse las siguientes diferencias: Primero, el sujeto activo se restringe a los progenitores del menor, sus ascendientes o sus familiares consanguíneos o por afinidad, hasta el segundo grado inclusive, convirtiéndose así en un delito especial propio ${ }^{32}$. Otra diferencia es que el propio artículo 225 bis altera lo que se había entendido por sustracción, ya que en su número 2 define dicha expresión, incorporando, a ella, una hipótesis de genuina retención ${ }^{33}$.

\footnotetext{
${ }^{31}$ Para el estudio y análisis del nuevo tipo penal de sustracción de menores en el Código Penal Español, ver GARCÍA, Octavio, "El delito de sustracción de menores y su configuración”, InDret N 4 (2010), disponible en: http://www.indret.com/pdf/767_es.pdf, [visitado el 28.05.2015].

${ }^{32}$ GARCÍA, "El delito de sustracción", cit. nota n 31, p.12.

33 "La retención de un menor incumpliendo gravemente el deber establecido por resolución judicial o administrativa".
} 
Con esta nueva redacción, el bien jurídico protegido es, sin lugar a dudas, algo distinto a la libertad o seguridad del menor, yendo hacia la protección de los derechos de tutela y otros similares $^{34}$. García Pérez sostiene que se está ante un "delito pluriofensivo en el que, además del bienestar personal del menor, se afecta al buen funcionamiento de los poderes públicos". 35 Prueba de ello es que la jurisprudencia española ha exigido, para apreciar este delito, la existencia de una resolución judicial o administrativa de atribución de la custodia previa $^{36}$. De esta forma, se ha concluido en más de alguna oportunidad que no cabe "fundamentar la realización del tipo del art. 225 bis del CP allí donde lo que existe es una mera guarda de hecho". 37

\subsection{Acción típica.}

La norma es inequívoca en este sentido, ya que castiga la sustracción de un menor de dieciocho años, por tanto, la acción típica es sustraer.

Los autores han sido muy homogéneos en este punto. Etcheberry ha expresado "el término sustracción indica la idea de quitar al menor de la esfera de cuidado y dependencia en que se encuentra". ${ }^{38}$ Labatut señala que "substraer significa apartar al menor de la esfera de cuidado y vigilancia en que se encuentra, permanente, transitoria o accidentalmente, y sea que la custodia emane de una situación de hecho o de derecho". 39 Politoff, Matus y Ramírez sostienen, al respecto, que "sustraer significa básicamente sacar al menor de la esfera de resguardo en que se encontraba". "Garrido concuerda con los autores ya citados, y afirma que "el comportamiento prohibido es sustraer a un menor de edad, sacarlo de la esfera de custodia en que se encuentra". ${ }^{41}$ Hermosilla, al tratar el tema, sostuvo que sustraer se refiere a quitar al menor del lugar donde estaba, específicamente del ámbito de resguardo, protección o dependencia que le corresponde ${ }^{42}$. Julio Zenteno entiende que la acción típica consiste en "apartar al menor de la esfera de cuidado y vigilancia en que se encuentra, permanente, transitoria o accidentalmente, y sea que la custodia emane de una situación de hecho o de derecho (padres, guardadores, maestros, niñeras, etc.)" 43

\footnotetext{
${ }^{34}$ Francisco Muñoz Conde recalca que "lo primero que hay que decir es que no se trata de unas detenciones ilegales, que, fuera de los casos previstos en el art. 225 bis, siguen siendo punibles en base a los arts. 163 y ss. (...), sino más bien de un delito de desobediencia a la decisión judicial respecto da la custodia y guardia de los hijos menores en caso de separación o divorcio de sus progenitores". MUÑOZ CONDE, Francisco, Derecho Penal, Parte Especial, 17ª Edición, Valencia: Tirant lo Blanch, 2009, p. 304.

${ }_{35}^{35}$ MUÑOZ CONDE, Derecho Penal, cit. nota n ${ }^{\circ} 34$, p. 9.

${ }^{36}$ MUÑOZ CONDE, Derecho Penal, cit. nota $n^{\circ} 34$, p. 14. En la nota al pie $n^{\circ} 42$ se cita abundante jurisprudencia.

${ }^{37}$ MUÑOZ CONDE, Derecho Penal, cit. nota n ${ }^{\circ} 34$, p. 16.

${ }^{38}$ ETCHEBERRY, Derecho Penal, cit. nota ${ }^{\circ}$ 12, p. 211.

${ }^{39}$ LABATUT, Derecho Penal, cit. nota ${ }^{\circ} 16$, p. 33.

${ }^{40}$ POLITOFF/MATUS/RAMÍREZ, Lecciones de Derecho Penal, cit. nota ${ }^{\circ}$ 12, p. 212. De la misma opinión es Gustavo Balmaceda. Ver BALMACEDA, Gustavo, Manual de Derecho Penal, Parte Especial, Santiago: Librotecnia, 2014, p. 174.

${ }^{41}$ GARRIDO, Derecho Penal, cit. nota n ${ }^{\circ}$ 12, p. 397.

${ }^{42}$ HERMOSILLA, Sustracción de Menores, cit. nota ${ }^{\circ}$ 17, p. 31.

${ }^{43}$ ZENTENO, Julio, Modificaciones al Código Penal 1979 - 1983, Modificaciones Legales del Quinquenio 1979 - 1983, Santiago: Universidad de Chile, 1984, p. 255.
} 
ESCOBAR, Javier. "Faz objetiva del delito de sustracción de menores".

La doctrina comparada ha adoptado esta misma idea. Por ejemplo, Eugenio Cuello ${ }^{44}$ señala que "el elemento material del delito está integrado por el hecho de sustraer un menor de siete años. La materialidad del hecho consiste en sacar al menor de la esfera de la potestad y guarda de los padres, tutores o encargados por cualquier título de él (...)". ${ }^{45}$ Sebastián Soler, analizando el tipo penal de sustracción de menores consagrado en el artículo 146 del Código Penal de la Nación Argentina, norma que sanciona al que sustrajere a un menor de diez años del poder de sus padres, tutor o persona encargada de él, sostiene que "substraer, en este artículo, quiere significar la acción de apartar al menor de la esfera de custodia en que el menor se encuentra, confiada por la ley a los padres, tutores o a otros encargados, aunque éstos lo sean temporariamente". ${ }^{46}$

Es evidente que en este punto la doctrina presenta unanimidad, existiendo una opinión bastante consolidada consistente en que la acción típica del artículo 142 consiste en sustraer, y esto significa apartar al menor de la esfera de resguardo, protección o custodia en la que se encontraba.

Nuestra jurisprudencia, en las sentencias ya citadas, también se ha pronunciado sobre la acción típica. En sentencia Rit 172-2007 del Tercer Tribunal de Juicio Oral en lo Penal de Santiago se estuvo de acuerdo con la opinión mayoritaria en doctrina ${ }^{47}$, pero además se agregó que por esfera de custodia o cuidado se debe entender el espacio de protección que le brindan al menor las personas obligadas por ley a ello y también aquellas que no estando en dicha calidad adquieren ese deber por la situación especial en que se encuentran (por ejemplo, niñeras) ${ }^{48}$. El Tribunal de Juicio Oral en lo Penal de Antofagasta, en sentencia Rit 175-2009, señaló que sustraer significa sacar al menor de la esfera de resguardo, y además se requiere que el hechor inaugure fácticamente una nueva relación de esa índole con el ofendido $^{49}$.

Como se puede apreciar, en este específico asunto la concordancia entre nuestra jurisprudencia y doctrina es absoluta.

¿Debe ser permanente la sustracción, o que al menos se realice con dicho ánimo? En sentencia Rol 129-2007, la Iltma. Corte de Apelaciones de Punta Arenas señaló que:

"En la doctrina no se considera como elemento del tipo penal la permanencia y tanto es así que el Profesor Gustavo Labatut Glena, en su Tratado de Derecho Penal, tomo II, pág. 33, señala textualmente: Sustraer significa apartar al menor de la esfera de cuidado y vigilancia en que se encuentra, permanente, transitoria o accidentalmente, y sea que la custodia emane de una situación de hecho o de derecho". ${ }^{5}$

\footnotetext{
${ }^{44} \mathrm{Si}$ bien aludiendo al antiguo tipo penal de sustracción de menores. Sobre este aspecto me remito a lo dicho supra.

${ }^{45}$ CUELLO, Derecho Penal, cit. nota n ${ }^{\circ}$ 3, p.750.

${ }^{46}$ SOLER, Sebastián, Derecho Penal Argentino, $4^{a}$ Edición, Buenos Aires: Editorial Tea, 1987, p. 65.

${ }^{47}$ En el mismo sentido el Sexto Tribunal de Juicio Oral en lo Penal de Santiago, en sentencia Rit 120-2006, Considerando Décimo Cuarto, donde sostuvo que "sustraer describe como conducta punible el sacar a un menor de la esfera de cuidado en que se encuentra".

${ }^{48}$ Considerando Cuarto.

${ }^{49}$ Considerando Noveno.

${ }^{50}$ Considerando Tercero.
} 
La Iltma. Corte concluye que la hipótesis básica del artículo 142, contenida en su número 2, no contempla ninguna exigencia subjetiva especial -distinta del dolo-, y por tanto el ánimo de permanencia no es un elemento típico ${ }^{51}{ }_{-}{ }^{2}$.

Para finalizar este apartado, cabe hacer notar que una adecuada comprensión de la acción típica es de capital importancia para fijar el momento en que se consuma el ilícito. Si la acción típica, como ya hemos visto, es sustraer, "el delito se consuma en el momento en que el niño queda fuera de la esfera de la potestad de sus padres o de la guarda de sus tutores o encargados". ${ }^{53}$ En este mismo sentido se ha pronunciado Soler, al expresar que no es necesaria la consolidación del poder de un tercero sobre el menor, y que basta con sacarlo de la esfera de custodia en que se encontraba ${ }^{54}$.

\subsection{Sujeto activo.}

Al parecer, sería mayoritaria en nuestra doctrina la opinión que excluye, como sujetos activos, a las personas que tengan a su cargo el cuidado del menor y a los padres ${ }^{55}$. Lo anterior significa que estos, aun cuando no tengan a su cargo el cuidado del menor, por razones teleológicas o sistemáticas nunca pueden ser sujeto activo de este delito. Así, Etcheberry expresa que los padres no pueden ser sujeto activo de este delito, y razona en base a la alta penalidad y a un texto legal obsoleto ${ }^{56}$. Agrega que si uno de los bienes jurídicos es la seguridad del menor, de ordinario ésta no se verá afectada si el agente es uno de los padres ${ }^{57}$. Politoff, Matus y Ramírez comparten la idea de que los padres no pueden ser sujetos activos del delito en estudio, y señalan que "sujeto activo puede ser cualquiera, menos quien tenga a su cargo la seguridad del menor. Como no se trata aquí de una infracción a derechos tutelares, lo que importa es averiguar si la persona que toma al menor es de aquellas que por ley están a su cargo. Así, ni los padres ni los tutores o guardadores legales pueden cometer este delito". ${ }^{58}$ En el mismo sentido se han pronunciado Labatut ${ }^{59}$,

\footnotetext{
${ }^{51}$ Considerando Cuarto.

${ }^{52}$ La jurisprudencia española, en cambio, a la luz del nuevo artículo 225 bis "viene exigiendo que las conductas tanto de traslado como de retención supongan privar definitivamente del menor al custodio". Ver GARCÍA, "El delito de sustracción", cit. nota n² 28, p. 17.

${ }^{53}$ CUELLO, Derecho Penal, cit. nota ${ }^{\circ} 3$, p. 753.

${ }_{55}^{54}$ SOLER, Derecho Penal Argentino, cit. nota $n^{\circ} 43$, p. 65.

55 En la doctrina comparada también es posible encontrar opiniones en este sentido. Ver QUINTANO RIPOLLÉS, Tratado de la Parte Especial, cit. nota n ${ }^{\circ} 23$, pp. 934 y ss.

${ }^{56}$ Etcheberry sostiene su argumento a la luz de la antigua redacción de la atenuante especial contemplada para la sustracción de menores, que favorecía al agente que devolvía al menor a sus padres. Como la atenuante no distinguía, se decía que podía ser a cualquiera de los padres, incluso a aquel que no contaba con el cuidado del menor. Entonces, esta aparente contradicción con la atenuante especial llevó a Etcheberry a concluir que los padres nunca podían ser sujeto activo. Hoy en día este argumento no es procedente, ya que la actual redacción de la atenuante especial, contenida en el artículo 142 bis, solamente exige que la víctima sea devuelta sin daño, con lo cual los posibles receptores del menor son todos.

${ }^{57}$ ETCHEBERRY, Derecho Penal, cit. nota $\mathrm{n}^{\circ}$ 12, p. 212.

${ }^{58}$ POLITOFF/MATUS/RAMÍREZ, Lecciones de Derecho Penal, cit. nota ${ }^{\circ}$ 12, p. 211.

59 "En cuanto al sujeto activo, los penalistas alemanes e italianos (...) estiman que puede ser autor de este delito tanto un extraño como alguno de los padres que substrae al hijo de la persona que legal o judicialmente tiene su tuición. Este criterio es aplicable en Italia y Alemania, cuyas legislaciones penales conciben el secuestro de niños como una simple ofensa a los derechos tutelares; pero no en la nuestra en que este delito
} 
ESCOBAR, Javier. "Faz objetiva del delito de sustracción de menores".

Hermosilla $^{60}$, Zenteno $^{61}$, y el Tercer Tribunal de Juicio Oral en lo Penal de Santiago, en sentencia Rit $172-2007^{62}$.

De otra opinión sería Garrido, quien ha expuesto que el legislador no hizo exigencias respecto del sujeto activo, por tanto no se requieren características especiales ${ }^{63}$. En el mismo sentido se pronunció la Iltma. Corte de Apelaciones de Temuco, Rol 1.192-2008, citada por María Angélica San Martín, con comentario favorable desde la perspectiva del Ministerio Público ${ }^{64}$. La Iltma. Corte sostuvo que el actual artículo 142 del Código Penal constituye un tipo abierto, que no está restringido a ciertas o determinadas personas ${ }^{65}$. Agregó además que cuando nuestro legislador ha querido restringir el campo de aplicación del sujeto activo lo ha dicho expresamente, por ejemplo en el delito de abandono de personas desvalidas del artículo $347^{66}$.

\subsection{Sujeto pasivo y consentimiento del menor ${ }^{67}$.}

Respecto del sujeto pasivo, el artículo 142 es claro: La víctima debe tener menos de dieciocho años ${ }^{68}$. Sin embargo, en relación a este tópico cabe preguntarse por los efectos jurídicos de su eventual consentimiento.

El artículo 142 no dice nada al respecto, pero sí el artículo 357, norma que sanciona al que indujere a un menor de edad, pero mayor de diez años, a que abandone su hogar ${ }^{69}$. Según la

constituye un gravísimo atentado contra la libertad personal". LABATUT, Derecho Penal, cit. nota $\mathrm{n}^{\circ} 16, \mathrm{pp}$. 33 y 34.

60 "Nosotros podemos decir, sobre todo después del enfoque que hemos hecho del bien jurídico amparado, que cualquiera persona, menos los padres o guardadores del menor, puede caer en esta infracción". HERMOSILLA, Sustracción de Menores, cit. nota ${ }^{\circ}$ 17, p. 44.

61 "En cuanto al sujeto activo, los penalistas alemanes e italianos (...) estiman que puede ser autor de este delito tanto un extraño como alguno de los padres que substrae al hijo de la persona que leal o judicialmente tiene su tuición. Este criterio es aplicable en Italia y Alemania, cuyas legislaciones penales conciben el secuestro de niños como una imple ofensa a los derechos tutelares; pero no en la nuestra en que este delito constituye un gravísimo atentado contra la libertad personal". ZENTENO, Modificaciones al Código Penal, cit. nota $\mathrm{n}^{\circ} 40$, p. 255. Como se puede apreciar, Zenteno se limita a transcribir la opinión de Labatut.

${ }^{62}$ Considerando Cuarto. Curioso es el hecho de que el Tribunal invoca el argumento de Etcheberry, basado en el texto legal obsoleto de la atenuante especial. Ello por cuanto la sentencia es del año 2007, y la modificación a la atenuante especial fue en 1993.

${ }^{63}$ GARRIDO, Derecho Penal, cit. nota n ${ }^{\circ}$ 12, p. 398.

${ }^{64}$ SAN MARTÍN, María Angélica, "Sustracción de Menores, Tipo Penal susceptible de ser cometido por uno de los padres" (Comentario de Sentencia), Revista Jurídica del Ministerio Público N $^{\circ} 37$ (2008), pp. 272 a 277.

${ }^{65}$ Considerando Sexto.

${ }^{66}$ Considerando Séptimo.

${ }^{67}$ El consentimiento de la persona que tiene a cargo el cuidado del menor, y el objeto específico del consentimiento de ésta, se verá infra 2.3.

${ }^{68}$ El Anteproyecto de Código Penal de 2005 propone una significativa modificación en este punto. Su artículo 116, inciso primero, establece: "La sustracción de persona menor de doce años". El Proyecto de Nuevo Código Penal enviado por el Gobierno de Chile al Congreso Nacional, en marzo de 2014, siguió esta misma idea.

${ }^{69}$ La norma citada señala textualmente: "El que indujere a un menor de edad, pero mayor de diez años, a que abandone la casa de sus padres, guardadores o encargados de su persona, sufrirá las penas de reclusión menor en cualquiera de sus grados y multa de once a veinte unidades tributarias mensuales". 
doctrina mayoritaria ${ }^{70}$, si se interpretan sistemáticamente ambas disposiciones se llega a la siguiente conclusión: En caso de que la víctima tenga menos de diez años, su consentimiento es irrelevante, configurándose siempre un delito de sustracción de menores. Ahora, en caso de que la víctima tenga más de diez años y menos de dieciocho, es posible que su consentimiento válido ${ }^{71}$ desplace el delito del artículo 142, pudiendo aplicarse, si procede, el del artículo $357^{72}$.

En efecto, como la norma citada sanciona al que indujere a abandonar el hogar a un menor de dieciocho años pero mayor de diez, tal disposición es improcedente tratándose de personas menores de diez años. Respecto de éstas, solamente cabe aplicar el injusto del artículo 142. Sostener lo contrario significaría, por ejemplo, que la inducción al abandono del hogar de un menor de 7 años sería atípica, en circunstancias que si dicho menor tuviese 13 años la conducta desplegada se sancionaría en virtud del artículo 357.

Cabe agregar que parte de la doctrina ${ }^{73}$ y jurisprudencia ${ }^{74}$ han señalado que el delito de inducción al abandono del hogar exige que el agente obre con el propósito de atentar contra el estado civil del menor, atendida la ubicación del delito dentro de nuestro Libro II. ${ }^{75}$ Sin embargo, no podría estimarse este criterio como dominante, ya que la mayoría de la doctrina no hace alusión al mismo ${ }^{76}$, y también es posible encontrar sentencias en que el tribunal no alude al tema específico ${ }^{77}$.

\subsection{Atenuante especial del artículo 142 bis.}

El artículo 142 bis contiene una atenuante especial, la cual dispone:

"Si los partícipes en los delitos de secuestro de una persona o de sustracción de un menor, antes de cumplirse cualquiera de las condiciones exigidas por los secuestradores para devolver a la víctima, la devolvieren libre de todo daño, la pena asignada al delito se rebajará en dos grados. Si la devolución se realiza después de

\footnotetext{
${ }^{70}$ GARRIDO, Derecho Penal, cit. nota ${ }^{\circ}$ 12, pp. 398 y 399; POLITOFF/MATUS/RAMÍREZ, Lecciones de Derecho Penal, cit. nota n ${ }^{\circ}$ 12, pp. 212 y 213; ETCHEBERRY, Derecho Penal, cit. nota n ${ }^{\circ} 12$, pp. 212 y 213 ; HERMOSILLA, Sustracción de Menores, cit. nota n 17, pp. 50 y 51.

${ }^{71} \mathrm{Al}$ respecto, infra 2.3 .

72 En este sentido resolvió el Tribunal de Juicio Oral en lo Penal de Los Ángeles, en sentencia Rit 12-2009, condenando por inducción al abandono del hogar al agente, ya que la menor al momento de los hechos tenía diez años cumplidos, y habría consentido en el abandono.

${ }^{73}$ POLITOFF/MATUS/RAMÍREZ, Lecciones de Derecho Penal, cit. nota n ${ }^{\circ}$ 12, p. 213.

${ }^{74}$ Sentencia Iltma. Corte de Apelaciones de La Serena, de fecha 31 de octubre de 1934 (GT 1934, 272.273). La resolución es citada en POLITOFF/MATUS/RAMÍREZ, Lecciones de Derecho Penal, cit. nota ${ }^{\circ}$ 12. p. 213.

${ }^{75}$ El Párrafo III del Título VII se denomina "Crímenes y simples delitos contra el estado civil de las personas".

${ }^{76}$ Garrido, Etcheberry, Labatut y Hermosilla no se refieren al punto. Eugenio Cuello, si bien a propósito de la legislación española, sostenía expresamente que "el elemento subjetivo de este delito está integrado por la voluntad de inducir al menor con conciencia de su minoría de edad y con conciencia de hallarse en la casa de sus padres, tutores o encargados de su persona. Es indiferente el móvil que lo inspire, aun cuando fuere un móvil social", ver CUELLO, Derecho Penal, cit. nota n 3, p.756.

${ }^{77}$ Por ejemplo, el Tribunal de Juicio Oral en lo Penal de Los Ángeles, en sentencia Rit 12-2009.
} 
ESCOBAR, Javier. "Faz objetiva del delito de sustracción de menores".

cumplida alguna de las condiciones, el juez podrá rebajar la pena en un grado a la señalada en los dos artículos anteriores".

Esta atenuante especial se funda en razones político criminales ${ }^{78}$, ya que busca incentivar que los agentes del delito de secuestro o sustracción de menores devuelvan a su víctima libre de daño, estando dispuesto el legislador a rebajar la pena en hasta dos grados.

La exigencia "libre de todo daño" debe entenderse como exento del daño adicional al necesario para la comisión del delito ${ }^{79}$, ya que de lo contrario esta atenuante sería inaplicable. Por tanto, las lesiones provocadas al menor para concretar la sustracción, suponiendo que éste se resistiese, o las lesiones provocadas por las ataduras que los agentes le colocan a su víctima, no impedirán tener por configurada esta atenuante. Por ello, siempre debe atenderse al caso concreto y a sus circunstancias específicas, ya que es perfectamente posible que unas mismas lesiones en un caso impidan la configuración de la atenuante, y en otro caso la permitan.

Un tema discutido es qué ocurre cuando los agentes devuelven a la víctima, pero sin imponer condición alguna. Si uno se ciñe al texto literal de la ley, pareciera desprenderse que la atenuante especial exigiría que los agentes hayan impuesto alguna condición, ya que sólo así sabríamos si la devolución se cometió antes o después de cumplirse aquella. Según nuestra opinión, corresponde aplicar acá una analogía in bonam partem. En efecto, considerando el fundamento político criminal de la atenuante (incentivar la devolución de las víctimas de estos delitos, para evitar que sufran un daño mayor), no existe ninguna razón para no rebajar la pena de aquel agente que no impone condición alguna ${ }^{80}$. La analogía in bonam partem, si bien en nuestro medio es excepcional, no es completamente desconocida. El ejemplo más paradigmático, según nuestra opinión, es el artículo 75 en relación al 74, cuando esta última norma resulta ser más favorable para el imputado. En conclusión, entendemos que la atenuante especial opera tanto si el agente impuso o no alguna condición. En los casos en que no se imponga ninguna condición, y la víctima sea devuelta libre de todo daño, el juez deberá rebajar dos grados, ya que se entenderá que la devolución se produjo "antes de cumplirse cualquiera de las condiciones", pues éstas ni siquiera se impusieron.

Finalmente, cabe afirmar que esta atenuante especial es de índole subjetiva, es decir, concurrirá sólo respecto de aquellos partícipes que tengan la intención de devolver a la víctima. Lo anterior se desprende del fundamento político criminal de la atenuante: Si el

\footnotetext{
${ }^{78}$ En el mismo sentido OLIVER, Guillermo, "Acerca de la retención de las víctimas en la comisión de un delito de robo con violencia o intimidación en las personas. A propósito de un caso real. Comentario a la sentencia del Tribunal de Juicio Oral en lo Penal de Quillota de 22 de agosto de 2007, RIT 35-2007”, Política Criminal $\mathrm{N}^{\circ} 4$ (2007), pp. 1 a 16, p. 12, disponible en http://www.politicacriminal.cl/n_04/d_6_4.pdf [visitado el 14.07.2015].

${ }^{79}$ POLITOFF/MATUS/RAMÍREZ, Lecciones de Derecho Penal, cit. nota ${ }^{\circ}$ 12, p. 206; BALMACEDA, Manual de Derecho Penal, cit. nota ${ }^{\circ} 40$, p. 166.

${ }^{80}$ A favor de la aplicación de la atenuante especial a las hipótesis de secuestro simple, OLIVER, "Acerca de la retención de las víctimas", cit. nota $\mathrm{n}^{\circ} 78$, pp. 13 y 14. En contra de la aplicación de la atenuante a estos supuestos, se pronunció el Tribunal de Juicio Oral en lo Penal de Quillota, en sentencia Rit 35-2007, Considerando Décimo Octavo.
} 
objetivo de ésta es incentivar la devolución de la víctima, aquel coautor o partícipe que estaba en contra de devolverla no debe beneficiarse de la rebaja de pena.

\section{Aspectos problemáticos del aparente consenso.}

En este segundo capítulo se pretende revisar críticamente el consenso anteriormente expuesto. El primer apartado de este capítulo tratará la relación existente entre los bienes jurídicos protegidos, la acción típica y el sujeto activo del delito. El segundo apartado abordará algunos casos concretos en los cuales no es aplicable el tipo penal de sustracción de menores, y propondremos la aplicación de otras figuras típicas. En el tercer apartado estudiaremos los medios comisivos en el delito de sustracción, colocando especial énfasis en el engaño como medio idóneo. En el cuarto y último acápite, analizaremos sucintamente la relación existente entre el delito de sustracción de menores y otros tipos penales afines, con los cuales se pueden plantear eventuales relaciones concursales.

\section{1. ¿Cuáles son los sujetos activos del delito in comento?: Una necesaria reflexión sobre los bienes jurídicos protegidos y la acción típica.}

Tanto el bien jurídico protegido por el delito de sustracción de menores como la acción típica son relevantes para determinar el sujeto activo del delito.

Respecto del bien jurídico, concordamos con la doctrina nacional en el sentido de que los derechos tutelares y el estado civil del menor no son protegidos directamente por el delito en estudio. Compartimos todos los argumentos esgrimidos a favor de esta tesis, pero agregamos uno que, desde nuestro punto de vista, es decisivo para clarificar el asunto. En este sentido, si uno revisa el artículo 354 inciso segundo, se dará cuenta que dicha norma sanciona, entre otras cosas, la sustracción de un hijo legítimo o ilegítimo con el ánimo verdadero o presunto de hacerle perder su estado civil. La pena con la que se conmina este comportamiento es la de presidio menor en sus grados medio a máximo. Como se puede apreciar, ambos tipos penales, el del artículo 142 y el del artículo 354 inciso segundo, suponen la sustracción de un menor, por tanto ambos delitos están en una relación concursal. Ésta relación no puede ser la de un concurso aparente, ya que no sería razonable que el artículo 354 inciso segundo contemplara un régimen más benigno para el agente en caso de que éste tenga una específica finalidad, cual es la de atentar contra el estado civil del menor. No nos parece razonable por cuanto dicha finalidad representa un plus de disvalor en relación con la hipótesis básica del artículo 142, la cual se configura sin exigir ninguna finalidad especial. Sería absurdo sostener que cuando el agente tenga la intención de atentar contra el estado civil del menor recibirá una pena menor a cuando no tenga dicha finalidad. Entonces, como ambos delitos no forman un concurso aparente la única opción que queda es concursarlos real o idealmente. Lo anterior demuestra que los derechos tutelares y el estado civil del menor no se ven protegidos por la sustracción de menores del artículo 142, sino que por los delitos contemplados en los artículo 353 y siguientes.

Los bienes jurídicos tutelados serían, entonces, la libertad del menor y su seguridad personal, pero con una precisión: La importancia de cada uno de estos dos bienes jurídicos varía en cada caso concreto. La lesión de cada uno de los bienes jurídicos protegidos aporta 
ESCOBAR, Javier. "Faz objetiva del delito de sustracción de menores".

un contenido de injusto, hasta completar el disvalor total contemplado por el legislador. En los menores más pequeños, piénsese en alguien de 3 años, su libertad es prácticamente inexistente, de modo tal que en el caso de sustracción de un menor con estas características, el principal bien jurídico tutelado será la seguridad. La lesión de ésta aportará el mayor contenido de injusto al disvalor global. En cambio, si concebimos la sustracción de un menor de diecisiete años, inmediatamente nos daremos cuenta de que el principal bien jurídico será la libertad de dicho adolescente, y no su seguridad personal. Podría decirse, entonces, que la importancia de la libertad y la de la seguridad están en una relación inversamente proporcional. El legislador ha reconocido esto, en el mismo artículo 357. En efecto, cuando el menor supera los diez años, su libertad ha adquirido mayor relevancia en comparación a la seguridad, y por ello, si consiente en abandonar el hogar, inducido por un tercero, no habrá sustracción de menores ${ }^{81}$.

Es importante señalar que los bienes jurídicos protegidos, según nuestra opinión, no excluyen a ningún potencial sujeto activo, ya que tanto un padre como un tercero pueden atentar contra ellos. De esta forma, discrepamos de la doctrina mayoritaria ${ }^{82}$, en el sentido de contemplar una presunción de derecho en favor de los padres, excluyéndolos sin más del círculo de posibles sujetos activos de este delito.

Respecto de la acción típica, ésta sí excluye, atendida su naturaleza, a ciertas personas del círculo de posibles sujetos activos del delito. En efecto, no podrá cometer sustracción aquella persona que tenga dentro de su esfera de custodia al menor ${ }^{83}$. Podrá ser la madre o el padre, pero también alguien a quien se le ha confiado el cuidado del menor accidentalmente, algún amigo de la familia, la profesora del jardín infantil, etc. De esta forma, el que se niega a entregar a un menor que está bajo su esfera de cuidado no comete el delito de sustracción de menores. Podrá cometer, como se verá infra 2.2, otros delitos, pero no el ilícito del artículo 142. Esto es de toda lógica: Si se define la sustracción como sacar al menor de la esfera de custodia en la que se encontraba, el mantener al menor, aun en contra de su voluntad, dentro de la esfera en la que se encuentra, no puede ser una sustracción.

De esta forma, concordando el bien jurídico tutelado y la acción típica, podemos concluir que, en principio, no hay ninguna razón para excluir a priori a los padres de los sujetos activos del delito de sustracción de menores ${ }^{84}{ }^{85}$.

\footnotetext{
${ }^{81}$ Ver supra 1.5 .

${ }^{82}$ Supra 1.4.

${ }^{83}$ Garrido señala que "la sustracción de menores no comprende la situación de una persona que de hecho tiene a un menor en su poder -sea porque asumió la custodia de facto o no tiene un derecho preferente para hacerlo- y se niega a entregarlo a aquella a quien le corresponde legalmente esa custodia". GARRIDO, Derecho Penal, cit. nota ${ }^{\circ} 12$, p. 397.

${ }^{84}$ En este sentido, concuerdo plenamente con la sentencia Rol 1.192-2008 de la Iltma. Corte de Apelaciones de Temuco.

${ }^{85}$ Se discrepa en este punto de Hermosilla, quien sostiene que "aun cuando el cuidado personal del menor se haya entregado a uno de los cónyuges, no cae en esta infracción el otro cónyuge que arrebata al hijo común, pues la acción no es típica, por no apartarse al menor de su esfera de protección". No se entiende cómo un padre que no tiene la tuición del menor, pueda tenerlo dentro de su "esfera de custodia". HERMOSILLA, Sustracción de Menores, cit. nota n ${ }^{\circ}$ 17, p. 44.
} 


\section{Polít. crim. Vol. 10, № 20 (Diciembre 2015), Art. 2, pp. 468-497. \\ [http://www.politicacriminal.cl/Vol_10/n_20/Vol10N20A2.pdf]}

No podemos finalizar este apartado sin antes efectuar una crítica de lege ferenda. Si los bienes jurídicos protegidos son la libertad y la seguridad individual, nos parece excesivo el límite de dieciocho años que contempla el artículo 142. En efecto, cuando el menor ya es un adolescente, pareciera que el delito de sustracción de menores protege solamente, o casi en su totalidad, la libertad. Particularmente revelador sobre este punto son las antiguas redacciones de este delito, tanto en la versión original del Código Penal Chileno como en el Código Penal Español de 1848. Recordemos que este último cuerpo legal sancionaba la sustracción de un menor de siete años, y nuestro Código Penal original hacía una importante diferencia penológica dependiendo de si el menor sustraído tenía más o menos de diez años. Así, nos parece que la propuesta contenida en el Anteproyecto de Código Penal de 2005, y en el Proyecto de Nuevo Código Penal enviado por el Gobierno de Chile al Congreso nacional, en marzo de 2014, en orden a limitar la edad del sujeto pasivo a doce años, es positiva.

\section{2. ¿Qué figuras típicas podrían aplicarse en casos en que la sustracción de menores no sea procedente?}

Tal como dijimos supra 2.1, la acción típica y los bienes jurídicos tutelados imponen ciertas restricciones al campo de aplicación de la sustracción de menores. Por ello, a continuación plantearemos y solucionaremos algunos casos problemáticos, revisando qué tipos penales podrían aplicarse y cuáles no.

2.2.1. Los padres, tutores o guardadores que detienen o encierran a un menor que se encuentra dentro de su esfera de resguardo.

Primero que todo, recordemos que en estos casos la sustracción de menores no será aplicable, al ser imposible hablar de una sustracción propiamente tal. En efecto, si el menor se encuentra dentro de la esfera de custodia del adulto que lo encierra o detiene, él jamás salió de dicha esfera, y por tanto no puede haber sustracción en los términos que lo ha entendido la doctrina ${ }^{86}$.

Ahora bien, debemos reconocer que dentro de esta hipótesis los casos pueden ser múltiples. Por ejemplo, entre un caso y otro puede haber diferencias sustanciales en cuanto al tiempo en que estuvo encerrado el menor, al lugar donde se encontraba, etc. Como las constelaciones fácticas son muchísimas, la única opción posible es dar respuestas generales con criterios valorativos.

Así, si un padre, tutor o guardador encierra o detiene a un menor durante un insignificante periodo de tiempo, por ejemplo, impidiéndole salir de su casa en plena noche, o que cruce la calle con luz roja, dicho encierro o detención probablemente podría encuadrar en un riesgo socialmente permitido, y ser atípico ${ }^{87}$. Por riesgo permitido entendemos aquel riesgo jurídicamente relevante, pero que de modo general está permitido y por ello, a diferencia de

\footnotetext{
${ }^{86}$ Supra 1.3 .

${ }^{87}$ Lo mismo sucede cuando el conductor del microbús no se detiene en el lugar solicitado, sino que lo hace algunas cuadras más adelante, impidiéndome descender del vehículo en el momento en que lo deseo, o cuando las autoridades del establecimiento educacional impiden que sus alumnos se vayan del mismo.
} 
ESCOBAR, Javier. "Faz objetiva del delito de sustracción de menores".

las causas de justificación, excluye ya la imputación al tipo objetivo ${ }^{88}$. El poder de corrección de los padres, reconocido desde tiempos inmemoriables, podría constituir la fuente del riesgo permitido en estos casos. Hoy en día dicho poder de corrección está contemplado en el artículo 234 del Código Civil, en los siguientes términos: "Los padres tendrán la facultad de corregir a sus hijos, cuidando que ello no menoscabe su salud ni su desarrollo personal". Si bien el poder de corrección ha sido limitado con el correr de los años, nos parece innegable que hoy en día el mismo puede cubrir ciertas acciones que buscan reprimir conductas de sus hijos.

Distinta sería la situación si tal encierro o detención superan el periodo insignificante, y por tanto ya no pueden encuadrarse en el riesgo permitido. En este caso, son cinco los tipos penales que aparecen como posibles: El delito-falta de coacciones, contenido en el artículo $494 \mathrm{~N}^{\circ} 16$, el secuestro, contenido en el artículo $141^{89}$, el delito de amenazas, contenido en los artículos 296 y 297, el delito de maltrato habitual, contemplado en el artículo 14 de la ley 20.066, y el delito de retención de menores, contemplado en el artículo 355 primera parte $^{90}$.

¿De qué dependerá si se aplica una u otra figura típica? Ello dependerá básicamente de la estructura de cada tipo penal, y de las reglas del concurso aparente.

Por ejemplo, en relación al delito de maltrato habitual, éste requiere para su configuración más de un episodio de violencia intrafamiliar. En efecto, el artículo 14 de la ley 20.066 exige el ejercicio habitual de violencia física o psíquica respecto de alguna de las personas referidas en el artículo $5^{\circ}$ de dicha ley.

Ahora, en relación al delito de retención de menores, para tener por configurado este delito se exigen requisitos muy específicos, tales como que haya una solicitud de devolución, y la persona que lo tenga a cargo esté amparada por algún título legítimo, cuestión que se infiere de la expresión "el que hallándose encargado" ". De esta forma, si no concurre alguno de estos dos requisitos no se podrá tener por configurado este delito.

A su vez, los tipos penales de amenazas y coacciones se refieren a situaciones también específicas. Es posible imaginar casos donde se configure el tipo penal de coacciones, pero no el de amenazas. También es posible imaginar situaciones en que se configure un secuestro sin amenazas, y así sucesivamente.

\footnotetext{
${ }^{88}$ ROXIN, Claus, Derecho Penal, Parte General, T. I, Trad. LUZON PEÑA, Diego Manuel; DÍAZ Y GARCÍA, Miguel; DE VICENTE, Javier, Madrid: Civitas, 1997, p. 371.

${ }^{89}$ Hermosilla intuye este punto, pero, según nuestra opinión, no da una respuesta satisfactoria. En efecto, el autor señala que en estos casos se aplicará el delito de secuestro, pero no distingue entre los diversos grados de afectación o gravedad que puede tener el encierro o la detención. HERMOSILLA, Sustracción de Menores, cit. nota ${ }^{\circ} 17$, p. 44.

90 "El que hallándose encargado de la persona de un menor no lo presentare, reclamándolo sus padres, guardadores o la autoridad".

${ }_{91}$ Profundizar sobre este delito en específico excedería los propósitos del presente trabajo.
} 
¿Cómo se relaciona lo anteriormente dicho con el sujeto pasivo en el delito de secuestro? Según la doctrina unánime ${ }^{92}$, el sujeto pasivo del delito de secuestro debe ser una persona de dieciocho años o mayor. Discrepamos de esta interpretación, por dos razones: Primero, porque la ley no lo exige, y por tanto constituye una limitación injustificada del ámbito de protección penal, y segundo, porque todos los casos que enunciamos recién podrían no recibir una respuesta penal adecuada. Piénsese en aquel padre que encierra a su hijo de diez años durante un largo periodo de tiempo. Como el menor estaba dentro de su esfera de resguardo, no hay sustracción, pero como el menor tenía menos de dieciocho años, tampoco habría secuestro. La doctrina al parecer no se ha dado cuenta de este inconveniente. En efecto, Etcheberry sostiene, sin explicación alguna, que "si la víctima es menor de dicha edad, el delito es el de sustracción de menores".93 Politoff, Matus y Ramírez, señalan que si la víctima "es menor de dieciocho años, la figura es la sustracción de menores". ${ }^{94}$ A su vez, Garrido plantea que la víctima debe ser una persona natural y tener por lo menos dieciocho años de edad, de no ser así, estaríamos ante una sustracción de menores ${ }^{95}$. No se entiende por qué la doctrina, después de tratar adecuadamente la acción típica del delito de sustracción de menores, sin más aseguran que el sujeto pasivo del delito de secuestro debe ser un mayor de dieciocho años, sin detenerse en las graves y negativas consecuencias que ello provoca. Debido a lo anterior, somos de la opinión de que el sujeto pasivo del delito de secuestro es cualquier persona, y por tanto este delito es una figura amplia ${ }^{96}$.

2.2.2. Menores que no se encuentran dentro de alguna esfera de custodia, de modo tal que ninguna persona determinada ejerce derechos tutelares sobre ellos, ya sea jurídicos o de facto.

Este estado de "vagancia" -en un sentido amplísimo- puede ser transitorio o permanente. Será transitorio cuando el menor salga voluntariamente de su esfera de resguardo por un periodo de tiempo determinado, como por ejemplo cuando se vaya de vacaciones. En cambio, será permanente cuando no exista una probabilidad futura y cierta de que el menor vuelva a la esfera de resguardo que una vez lo cobijó, como por ejemplo cuando el menor ha sido abandonado y vive en las calles.

En la práctica será relativamente fácil determinar si el menor se encuentra en un estado de vagancia permanente, pero no así si se encuentra en un estado de vagancia transitorio. Esta cuestión tiene la máxima importancia, ya que, como lo sostendremos a continuación,

${ }^{92}$ ETCHEBERRY, Derecho Penal, cit. nota n ${ }^{\circ}$ 12, p. 203; POLITOFF/MATUS/RAMÍREZ, Lecciones de Derecho Penal, cit. nota $\mathrm{n}^{\circ}$ 12, p. 202; GARRIDO, Derecho Penal, cit. nota $\mathrm{n}^{\circ}$ 12, p. 389; BALMACEDA, Manual de Derecho Penal, cit. nota ${ }^{\circ} 40$, p. 162.

${ }^{93}$ ETCHEBERRY, Derecho Penal, cit. nota ${ }^{\circ}$ 12, p. 203.

${ }^{94}$ POLITOFF/MATUS/RAMÍREZ, Lecciones de Derecho Penal, cit. nota ${ }^{\circ}$ 12, p. 202.

${ }^{95}$ GARRIDO, Derecho Penal, cit. nota ${ }^{\circ} 12$, p. 389.

${ }^{96}$ Existe un caso en que nuestra jurisprudencia se pronunció en este mismo sentido. En sentencia Rol 27.4402001, de la Iltma. Corte de Apelaciones de Santiago, se condenó a los imputados como autores del delito de secuestro, en circunstancias que las víctimas eran menores de edad. Los hechos fueron, resumidamente, los siguientes: Los 3 autores trabajaban en un establecimiento comercial (1 de ellos como Administradores y los demás como guardias de seguridad). Con fecha 21 de enero de 1995, ingresaron a dicho establecimiento 6 menores de edad, cuyas edades oscilaban entre los once y los diecisiete años. Los imputados, tras observar a las víctimas durante un lapso determinado, sospecharon que éstas estaban hurtando al interior del establecimiento, razón por la cual, mediante fuerza e intimidación, los encerraron en una bodega y les causaron diversas lesiones y tormentos. 
ESCOBAR, Javier. "Faz objetiva del delito de sustracción de menores".

respecto de estos menores no se puede configurar el delito en estudio. Como las constelaciones posibles de estados de vagancia transitorios son infinitas, sólo es posible plantear un criterio normativo: Cuando el adulto responsable no esté en condiciones de ejecutar sus potestades de manera directa o a través de un tercero, de manera más o menos expedita, se podrá decir que el menor no está dentro una esfera de resguardo. Hay que ser muy prudentes en este punto, ya que, recordemos, la esfera de resguardo puede tener su origen en la ley o en una convención. Es perfectamente posible que el menor esté dentro de una esfera de custodia distinta a la que generalmente se encuentra. Los estados de vagancia transitorios constituyen una importante restricción fáctica de la aplicación del tipo penal de sustracción de menores.

¿Qué sucede si estos menores son detenidos o encerrados por un tercero?

La situación de estos menores es similar a la descrita en la letra anterior. Según nuestra opinión, estos menores no podrán ser víctima del delito de sustracción de menores, ya que al no estar dentro de ninguna esfera de custodia lógicamente no pueden ser sustraídos de ella. En efecto, si entendemos por sustraer la acción de apartar al menor de la esfera de custodia en la que se encuentra, si éste no está dentro de ninguna esfera de custodia malamente puede ser sustraído. Una interpretación distinta, estimamos, constituiría analogía in malam partem, proscrita en virtud del principio de legalidad. La única posibilidad de fundar una legítima aplicación del delito de sustracción de menores sería construyendo una esfera de resguardo del menor en estado de vagancia. Algunos podrían pensar que toda persona se encuentra siempre dentro de una esfera de custodia, ya que las personas ermitañas no existen en la sociedad actual. En este sentido, los niños vagos se agrupan con sus pares, con otros menores en estado de vagancia, de suerte que, podría plantearse, los menores ejercen derechos de custodia y tutela respecto de sus pares, como una suerte de esfera de custodia horizontal y recíproca. Creemos que dicha esfera de custodia no reviste la calidad exigida por el legislador, quien a todas luces estaba pensando en una esfera formalmente constituida, si bien no necesariamente "matrimonial", sí ejercida por un adulto responsable. Si los menores en estado de vagancia pudieran ejercer derechos de tutela respecto de sus pares, el campo de aplicación de la sustracción de menores se ampliaría en demasía, y cualquier detención o encierro de un menor de dieciocho años constituiría sustracción, incurriríamos en una desconceptualización de la esfera de resguardo, y terminaríamos por asimilarla con el lugar donde se encuentra el menor.

Recordemos la sentencia Rit 172-2007, del Tercer Tribunal de Juicio Oral en lo Penal de Santiago. El Tribunal en dicha oportunidad definió esfera de custodia como el espacio de protección que le brindan al menor las personas obligadas por ley a ello y también aquellas que no estando en dicha calidad adquieren ese deber por la situación especial en que se encuentran (por ejemplo, niñeras) ${ }^{97}$. De la opinión del Tribunal claramente se desprende que la esfera de cuidado debe ejercerse por un adulto, en ello estaba pensando nuestro legislador.

Ahora, lo anteriormente expuesto no significa de ninguna forma que el menor no será sujeto de protección penal. Es más, tanto Etcheberry como Hermosilla se dieron cuenta de

\footnotetext{
${ }^{97}$ Considerando Cuarto.
} 
que el derecho penal no podía darle la espalda a estos menores, e intentaron algunas soluciones.

Etcheberry señaló que "tratándose de los (...) niños vagos (...), la sustracción consistirá en conductas muy parecidas al secuestro: Encierro o detención". ${ }^{98}$ Lamentablemente, el autor no desarrolla el tema, de modo tal que no es posible concluir si él estaba a favor de aplicar igualmente el delito de sustracción de menores, o de aplicar el delito de secuestro.

Hermosilla también abordó el punto, y señaló:

“existen -para nuestra vergüenza- los niños que están en situación totalmente irregular, como, por ejemplo, los niños vagos, parias de la sociedad, faltos de familia y de protección estatal, y que se dan principalmente en las grandes ciudades; en estos casos no se verificaría la acción extrayendo al menor de una situación de amparo y custodia, sino al revés, de una situación carencial y de abandono. (...). ¿Habrá sustracción en estos casos? Ella se realizará aprehendiendo, reteniendo, encerrando u ocultando al menor (...). Básicamente equivale al contenido de la acción en el secuestro. Podría entones aplicarse esta figura, desplazando a la sustracción de menores; pero esto no sucede, porque hay un elemento objetivo que hace el papel diferenciador extratípico, de primerísima importancia. Es la edad del sujeto pasivo".99

El autor termina sosteniendo que estos casos deben calificarse como sustracción impropia, reservando la expresión sustracción propia cuando realmente se aparta al menor de una esfera de resguardo y dependencia. Creemos que la solución propuesta por el autor debe ser desestimada, en razón de que constituye analogía en perjuicio del reo, prohibida, según dijimos, por el principio de legalidad. En efecto, la ley es clara al establecer el verbo sustraer. Éste significa extraer al menor de su esfera de custodia, de modo tal que si no existe una esfera de protección en los hechos concretos no puede haber sustracción.

Clarificador es el tipo penal de hurto de hallazgo, contenido en el artículo 448. Éste castiga a todo aquel que se encuentre una cosa mueble, al parecer perdida, y no la entregue a la autoridad o a su dueño, siempre que le conste quién sea éste por hechos coexistentes o posteriores al hallazgo. ¿Por qué nuestro legislador creó este delito autónomo y no se contentó con tipificar el hurto? Pues bien, porque cuando alguien encuentra una cosa mueble perdida no existe esfera de custodia alguna sobre ella, y por tanto técnicamente no hay sustracción si esa persona se apodera de dicho bien. Si no existiese el tipo de hurto de hallazgo, la situación descrita por él no sería punible. Afirmar que los casos de hurto de hallazgo deberían penarse sancionarse al tipo de hurto infringiría el principio de legalidad.

La solución que consideramos correcta es la misma que se dio en la letra anterior, vale decir, analizar en el caso concreto qué tipo penal de los señalados se puede aplicar, respetando siempre los principios generales y los requisitos especiales de cada delito ${ }^{100}$.

\footnotetext{
${ }^{98}$ ETCHEBERRY, Derecho Penal, cit. nota n ${ }^{\circ} 12$, p. 211.

${ }^{99}$ HERMOSILLA, Sustracción de Menores, cit. nota ${ }^{\circ} 17$, p. 32.

${ }^{100}$ El tipo de maltrato habitual generalmente quedará descartado, debido a que en la mayoría de los casos, por no decir en la totalidad, no se dará la relación familiar que exige el artículo 5 de la ley 20.066.
} 
ESCOBAR, Javier. "Faz objetiva del delito de sustracción de menores".

\subsection{Consentimiento de la persona a cargo del menor y modalidades comisivas.}

El consentimiento de la persona que tiene al menor dentro de su esfera de custodia presenta dificultades prácticas. Al respecto, podemos señalar que, según nuestra opinión, dicho consentimiento constituye una causal de atipicidad si se presta antes de que se realice la "sustracción". Aun cuando el tipo penal no exija que la sustracción se lleve a cabo sin el consentimiento del adulto a cargo del menor, nos parece que ello fluye de la misma naturaleza del delito en cuestión ${ }^{101}$. El término mismo de sustracción supone falta de acuerdo por parte del cuidador. De esta forma, cuando el encargado del menor lo entrega a otra persona para que ésta cuide de él, no existe siquiera una acción de sustracción.

De esta forma, no estamos de acuerdo con Etcheberry, quien sostiene que el consentimiento de los padres o guardadores no tiene ningún efecto como causal de justificación, ya que "ellos no tienen derecho para disponer de la seguridad del menor, y por otra parte sus derechos de tutela y custodia no son sino la inseparable contrapartida de las obligaciones correlativas de las que ellos no pueden desligarse a voluntad". ${ }^{102}{ }_{-} 103$

Respecto de los medios comisivos, es decir, las diversas formas que puede adoptar la acción típica en el caso concreto, debemos expresar desde ya que estos son múltiples ${ }^{104}$. Dividiremos la exposición de los medios comisivos en dos apartados: Primero, trataremos la violencia o intimidación, medio que no presenta mayores dificultades, y en segundo lugar, abordaremos el engaño, ya sea sobre el menor o sobre el adulto encargado de éste.

\subsubsection{Medios idóneos.}

Como se señaló recién, la violencia o intimidación no presentan complejidades como medios idóneos para configurar el delito de sustracción de menores. Si el agente, mediante violencia, toma al menor y se lo lleva consigo, cometerá sustracción de menores sin duda alguna. Lo mismo sucederá si emplea intimidación, por ejemplo, si amenaza mediante un arma de fuego al menor y le exige que se vaya con él. La violencia o intimidación puede ser igualmente empleada contra un tercero, como el caso del autor que amenaza al padre del menor y obliga a éste a irse con él.

\footnotetext{
${ }^{101}$ Lo mismo ocurre en el delito de violación del artículo 361. Bien sabido es que, aun cuando el tipo penal no exige que la violación sea sin el consentimiento de la víctima, se ha entendido que si la víctima consiente en la relación sexual la acción es atípica. Ello porque de la naturaleza misma de la violación aparece como un elemento del tipo que la relación sexual sea sin el consentimiento de la víctima.

${ }^{102}$ ETCHEBERRY, Derecho Penal, cit. nota ${ }^{\circ} 12$, p. 213.

${ }^{103}$ Cabe destacar que el citado autor utiliza la expresión "causal de justificación", lo que significa que en su opinión el consentimiento del cuidador no es un elemento integrante del tipo penal. Si así fuera, el autor se referiría a "causal de atipicidad".

${ }^{104}$ En el mismo sentido, HERMOSILLA, Sustracción de Menores, cit. nota $\mathrm{n}^{\circ}$ 17, p. 31. También el Tercer Tribunal de Juicio Oral en lo Penal, en sentencia Rit 172-2007, donde sostuvo, en su Considerando Cuarto, que "en lo relativo a los medios de ejecución de este delito, ésos pueden ser múltiples y variados, siempre y cuando sean aptos para conseguir la separación o alejamiento del menor”.
} 
Polít. crim. Vol. 10, № 20 (Diciembre 2015), Art. 2, pp. 468-497.

[http://www.politicacriminal.cl/Vol_10/n_20/Vol10N20A2.pdf]

\subsubsection{El engaño.}

El engaño en cambio, sí presenta algunas dificultades. Para un adecuado estudio, se distinguirá si el engaño se dirige contra el menor o contra la persona a cargo de éste.

Engaño dirigido contra el propio menor: Se debe diferenciar si éste tiene más o menos de diez años. En el primer caso, según lo dicho anteriormente ${ }^{105}$, su consentimiento es irrelevante, por tanto se apreciará un delito de sustracción de menores sin más.

Ahora, en caso de que el menor tenga más de diez años, su voluntad cobra importancia para estos efectos, ya que no siempre y en todo caso se configurará un delito de sustracción de menores, pudiendo éste ser desplazado por el ilícito de inducción al abandono del hogar del artículo 357.

¿Qué condiciones o requisitos debe reunir, entonces, el engaño dirigido contra el menor para constituir acción típica de sustracción de menores? El engaño debe recaer y afectar la circunstancia de estar abandonando la esfera de resguardo, elemento que le otorga identidad a la acción de sustracción. Vale decir, si producto del engaño el menor no tiene conciencia de estar abandonado su esfera de custodia, estaremos ante una acción típica de sustracción de menores. A modo de ejemplo, si el autor le dice al menor que viene por instrucciones de su padre, y que debe irse con él, habrá sustracción de menores y no inducción al abandono del hogar, ya que el menor no sabe que está abandonando su esfera de resguardo. Éste cree precisamente lo contrario, que yéndose con este tercero se mantendrá en ella.

No habrá sustracción de menores, en cambio, cuando el menor comprenda que está abandonando su esfera de resguardo, a pesar de hacerlo motivado por consideraciones equivocadas, desventajosas o basadas en mentiras. Por ejemplo, si el autor le promete al menor matrimonio, dinero u otros bienes, no habrá sustracción de menores, ya que si bien existe un engaño, éste no versa sobre el hecho de estar abandonando la esfera de resguardo. En este caso podrá apreciarse un delito de inducción al abandono del hogar.

Engaño dirigido contra la persona encargada del menor: En este caso, debemos preguntarnos ¿qué consecuencias jurídicas acarrea un consentimiento viciado del adulto a cargo del menor? Para plantear mejor el problema, imaginemos un caso: El autor llega donde la madre de un menor y la engaña, diciéndole que debe entregarlo ya que él es funcionario del recinto asistencial de la ciudad, y su hijo debe ser vacunado en dicho lugar, como todos los demás menores. La madre entrega a su hijo, el agente se lleva al menor y desaparece.

¿Ante qué delito estaríamos? La pregunta formulada requiere analizar la calidad del consentimiento prestado por la madre y sus consecuencias jurídicas. No cabe ninguna duda de que el consentimiento de la madre en el caso planteado está viciado. En efecto, ella entrega al menor motivada por un engaño, debido a que el autor le señaló que era empleado del Estado, y su hijo debía recibir una vacuna en el centro asistencial más cercano. ¿Qué consecuencias jurídicas tiene este consentimiento viciado?

\footnotetext{
${ }^{105}$ Ver supra 1.5.
} 
ESCOBAR, Javier. "Faz objetiva del delito de sustracción de menores".

Según nuestra opinión, en este caso se configura el delito de sustracción de menores. Esto por cuanto el adulto no está consciente de que su esfera de custodia o resguardo se está destruyendo, sino que él cree que en la especie se configura un mandato de custodia. Así, la solución es la misma que en los casos anteriores: Si el engaño recae sobre el hecho de estar destruyendo de manera definitiva la esfera de custodia, habrá sustracción de menores. En cambio, si el engaño recae sobre otro elemento distinto, no se configurará el delito en estudio. Por ejemplo: Un agente intenta "comprar" a un menor, prometiendo una cuantiosa suma de dinero. El adulto a cargo del menor consiente en la "venta", y entrega al menor. El agente escapa, sin entregar dinero alguno. En este caso no puede haber sustracción de menores, ya que el cuidador era consciente de estar destruyendo su propia esfera de custodia, sin perjuicio de la eventual configuración de otros delitos.

Para finalizar este acápite, es menester citar una sentencia de 1956, en la cual nuestra Excma. Corte Suprema condenó a la encausada como autora del delito de sustracción de menores, en circunstancias que ella había obtenido mediante engaños la entrega del menor y luego había huido con él. ${ }^{106}$ La Excma. Corte, al rechazar el recurso de casación en el fondo, respalda la tesis de que el engaño es un medio comisivo apto para configurar la sustracción de menores.

\subsection{Relación entre el delito de sustracción de menores y otros tipos penales afines.}

En este último apartado me dedicaré a revisar las relaciones concursales que tiene el delito de sustracción de menores con otros tipos penales afines.

En relación a los delitos de secuestro, amenazas, maltrato habitual o delito-falta de coacciones, conforme a lo señalado supra 2.2, la configuración de un delito de sustracción de menores desplaza a los tipos penales indicados, en virtud de los distintos principios que regulan el concurso aparente de leyes. Por ejemplo, si el autor amenaza a la víctima o la detiene durante un corto periodo de tiempo, para luego finalmente sustraerla, estaremos ante un solo delito de sustracción de menores. El razonamiento expuesto no debiera suscitar ninguna objeción, ya que si consideramos la alta pena asignada al delito de sustracción de menores, afirmar que el mismo tiene una gran capacidad para absorber otros delitos afines que atenten contra bienes jurídicos similares resulta evidente. Respecto del delito de maltrato habitual, la relación de subsidiariedad es expresa ${ }^{107}$.

Ahora, pasando a los delitos que atentan contra el estado civil de las personas, el análisis se complejiza. Lo anterior debido principalmente al escaso o nulo tratamiento doctrinario que han recibido los delitos comprendidos bajo dicha denominación.

${ }^{106}$ ETCHEBERRY, Alfredo, El Derecho Penal en la Jurisprudencia, Sentencias 1875 - 1966, T. II, $1^{\mathrm{a}}$ Edición, Santiago: Editorial Jurídica de Chile, 1968, p. 414.

${ }^{107}$ El artículo 14 inciso primero de la Ley 20.066 establece: "El ejercicio habitual de violencia física o psíquica respecto de alguna de las personas referidas en el artículo $5^{\circ}$ de esta ley se sancionará con la pena de presidio menor en su grado mínimo, salvo que el hecho sea constitutivo de un delito de mayor gravedad, caso en el cual se aplicará sólo la pena asignada por la ley a éste". 
A continuación analizaremos sucintamente los delitos de sustitución de menores (artículo $353^{108}$ ), sustracción civil de menores (artículo 354 inciso segundo ${ }^{109}$ ), y la retención de menores (artículo $355^{110}$ ), ilícitos todos que, para su configuración, requieren la intención por parte del agente de atentar contra el estado civil de la víctima ${ }^{111}$.

En relación a la sustitución de menores, generalmente existirá una sustracción de menores del artículo 142 previa o coetánea. En efecto, si el agente pretende sustituir a un niño por otro, a menos que ambos estén dentro de su esfera de resguardo, estará obligado a cometer una sustracción de menores, y ésta puede ser previa a la sustitución o simultánea. Así, la sustitución de menores estará siempre en una relación de concurso real o ideal con la sustracción que se cometa, y no aparente, toda vez que los bienes jurídicos afectados son distintos. En efecto, el ánimo de atentar contra el estado civil del menor le agrega un plus de injusto a la sustracción del artículo 142. Dicho en palabras simples, uno puede sustraer por varios motivos, pero si dicho motivo es atentar contra el estado civil del menor, estaremos ante otro delito, que se concursará con la sustracción.

Lo mismo ocurre para el caso de la sustracción civil de menores del artículo 344 inciso segundo. En efecto, este inciso sanciona la misma acción típica que el artículo 142, esta es, sustraer un menor. Entonces, si la sustracción se lleva a cabo para atentar contra el estado civil del menor, se configurará un injusto autónomo, y estaremos ante un concurso real o ideal. Ello porque, al igual que en el delito de sustitución de menores, uno puede sustraer a un menor por múltiples razones, pero si en el caso concreto la finalidad es atentar contra este distinto bien jurídico, no sólo estaremos ante el disvalor de la sustracción de menores del artículo 142, sino que también ante el injusto del artículo 344 inciso segundo.

Respecto del delito de retención de menores, en supra 2.2.1 se señalaron sus requisitos. Al respecto, sólo cabe mencionar que la situación en la que se torna operativo el delito de retención de menores convierte en improcedente el delito de sustracción de menores. Ello se debe a que el primer delito requiere, para su configuración, que el agente tenga a su cargo el cuidado del menor, y por tanto, que lo tenga dentro de su esfera de resguardo. Así, no puede haber sustracción de un menor que se encuentra dentro de la esfera de custodia del agente, lo cual pone a ambos delitos en una situación de exclusión mutua.

Para terminar este acápite, es pertinente mencionar el delito contenido en el artículo 41 de la ley 19.620. Dicha norma sanciona al que "con abuso de confianza, ardid, simulación,

\footnotetext{
108 “Art. 353. La suposición de parto y la substitución de un niño por otro, serán castigados con las penas de presidio menor en cualquiera de sus grados y multa de veintiuna a veinticinco unidades tributarias mensuales".

109 “Art. 354. (...) Las mismas penas se impondrán al que substrajere, ocultare o expusiere a un hijo legítimo o ilegítimo con ánimo verdadero o presunto de hacerle perder su estado civil".

110 "Art. 355. El que hallándose encargado de la persona de un menor no lo presentare, reclamándolo sus padres, guardadores o la autoridad, a petición de sus demás parientes o de oficio, ni diere explicaciones satisfactorias acerca de su desaparición, sufrirá la pena de presidio menor en su grado medio".

${ }^{111}$ La reflexión acabada sobre los ilícitos mencionados, el estudio de su tipicidad objetiva y subjetiva, etc., es probablemente inabarcable en el contexto del presente trabajo. Por dicha razón, nos limitaremos a esbozar algunas ideas generales a su respecto, con la sola finalidad de esclarecer sus relaciones concursales con el ilícito de sustracción de menores.
} 
ESCOBAR, Javier. "Faz objetiva del delito de sustracción de menores".

atribución de identidad o estado civil u otra condición semejante, obtuviere la entrega de un menor para sí, para un tercero, o para sacarlo del país, con fines de adopción”. El comentario de este delito estará íntimamente ligado con el tema tratado supra 2.3, este es, el engaño como medio comisivo de la sustracción de menores. Según nuestra opinión, este delito no excluye el delito de sustracción de menores, por lo tanto, si en un caso concreto ambos se presentan, deberán concursarse real o idealmente ${ }^{112}$.

\section{Conclusión.}

El delito in comento encuentra su fundamento en la gravedad intrínseca del atentado. En efecto, éste se dirige contra la seguridad personal y la libertad del menor, y allí radica su injusto. Ahora, ambos bienes jurídicos se encuentran en una relación de importancia relativa. Esto significa que conforme al desarrollo normal del menor, la seguridad personal va cediendo en importancia ante la libertad ambulatoria. Ambos bienes tutelados se encuentran, así, en una relación inversamente proporcional.

Se descarta como bien jurídico tutelado las relaciones filiales o la patria potestad. Los argumentos para ello son diversos -ubicación sistemática, pena asignada al delito, etc.-, siendo decisivo, a nuestro entender, la existencia del delito de sustracción civil de menores, contenida en el artículo 354 inciso segundo. En efecto, la acción típica tanto en este delito como en el del artículo 142 es la misma, a saber, sustraer. La diferencia entre ambas figuras típicas radica en la motivación subjetiva del agente, toda vez que, en el caso de esta última norma, se exige que la conducta se realice con el ánimo verdadero o presunto de hacerle perder a la víctima su estado civil.

El sujeto pasivo debe ser un menor de dieciocho años, y encontrarse dentro de una esfera de resguardo. Ello por cuanto la acción típica -sustraer- debe entenderse como apartar o sacar al menor de dicha esfera de custodia, de aquel espacio jurídico-fáctico dentro del cual un adulto responsable ejerce derechos de tutela y cuidado sobre él. Si no existe una esfera de cuidado identificable no podrá haber sustracción, sin perjuicio de la eventual configuración de otros delitos.

Respecto del sujeto activo, se discrepa abiertamente de la doctrina mayoritaria actual, en el sentido de excluir a los padres del menor del círculo de sujetos activos. Según nuestra opinión, no existe fundamento normativo ni teleológico para fundamentar dicha exclusión. Los padres perfectamente pueden atentar contra los bienes jurídicos tutelados por el delito analizado. El sujeto activo del delito de sustracción de menores es cualquier persona, excepto aquella que tenga al menor dentro de su esfera de resguardo, toda vez que en este caso no es posible apreciar una sustracción. Respecto de la persona que detiene o encierra

\footnotetext{
${ }^{112}$ Cabe citar la sentencia Rol 10-2008 de la Excma. Corte Suprema, donde se rechazó un recurso de casación en el fondo interpuesto por la defensa de la imputada, que había sido condenada en primera y en segunda instancia como autora del delito contenido en el artículo 41 de la ley 19.620. Lamentablemente, debido a que la defensa había interpuesto el recurso, y a que la acusación nunca consideró la posibilidad de enjuiciar a la encausada además por el delito de sustracción de menores, la Excma. Corte Suprema no se pudo pronunciar sobre la relación concursal entre ambos ilícitos.
} 
Polít. crim. Vol. 10, № 20 (Diciembre 2015), Art. 2, pp. 468-497.

[http://www.politicacriminal.cl/Vol_10/n_20/Vol10N20A2.pdf]

al menor, teniendo a éste dentro de su esfera de custodia, podrán configurarse eventualmente otros delitos, pero no el de sustracción de menores.

Creemos que la acción típica del delito en estudio debe de una vez por todas tomarse en cuenta, y sistematizarse adecuadamente con los demás tipos penales, principalmente con el de secuestro. La sustracción de menores no es un secuestro impropio o calificado, sino que es un delito distinto. Mientras el tipo de secuestro aparece como una figura típica amplísima, tanto respecto a su acción como a los sujetos que intervienen, el de sustracción de menores se muestra como una figura típica restringida en cuanto a la víctima y a la conducta incriminada.

Sobre los medios comisivos, destacamos el engaño. Éste podrá dirigirse contra la persona a cargo del menor o contra este mismo. Ahora bien, no cualquier engaño configurará un delito de sustracción de menores, sino que solamente aquel que recaiga sobre un hecho específico: Estar destruyendo o abandonando la esfera de custodia vigente. Así, por ejemplo, si el menor no sabe que está abandonando su esfera de resguardo se configurará una sustracción de menores. Al contrario, si el menor es consciente de esto, mas accede motivado por razones desventajosas o incorrectas, no habrá sustracción de menores.

El consentimiento del menor también acarrea consecuencias prácticas de primera importancia. Consideramos que la sistematización realizada por la doctrina de los artículos 142 y 357 es correcta. La única salvedad que hicimos a lo largo de este trabajo es que un consentimiento viciado o errado por parte del menor puede desplazar el delito de inducción al abandono del hogar. La decisión de abandonar el hogar debe poder imputársele al menor como propia, producto de su autonomía.

Por último, aun cuando en este trabajo se intentó delimitar la sustracción de menores de otros tipos penales, ya sea concursándolos aparente, real o idealmente, creemos que todavía resta mucho por hacer sobre este punto. Las diferencias entre sostener un concurso ideal, real o aparente son demasiado importantes como para relegar dicha tarea a la incertidumbre. Acá se sostuvo que los delitos que atentan contra el estado civil, en relación a la sustracción de menores, representan un plus de injusto, y por ello no cabe concursarlos aparentemente, sino que siempre deberá apreciarse un concurso real o ideal. Prueba evidente de ello es la sustracción de menores del artículo 344 inciso segundo. 
ESCOBAR, Javier. "Faz objetiva del delito de sustracción de menores".

\section{BIBLIOGRAFÍA}

Actas de las Sesiones de la Comisión Redactora del Código Penal de Chile.

BALMACEDA, Gustavo, Manual de Derecho Penal, Parte Especial, Santiago: Librotecnia, 2014.

BUSTOS, Juan, Manual de Derecho Penal, Parte Especial, 2ª Edición, Barcelona: Ariel, 1991.

CARRARA, Francisco, Programa del Curso de Derecho Criminal, T. V, Parte Especial, Buenos Aires: Editorial Palma, 1946.

COBO, Manuel, "Consideraciones Técnico-Jurídicas sobre la Sustracción de Menores", Separata de Anuario de Derecho Penal y Ciencias Penales, Madrid: Instituto Nacional de Estudio Jurídicos, 1961.

CORTÉS, Emilio, Aspectos de los Delitos contra la Filiación y Nueva Regulación del Delito de Sustracción de Menores, Madrid: Instituto de Criminología, 1996.

CUELLO, Eugenio, Derecho Penal, T. II, V. $2^{\circ}, 14^{\mathrm{a}}$ Edición, Barcelona: Bosch Casa Editorial, 1982.

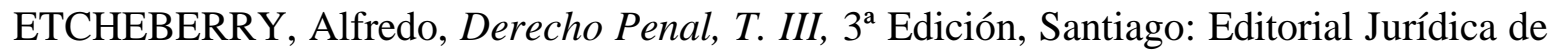
Chile, 1998.

, El Derecho Penal en la Jurisprudencia, Sentencias 1875 - 1966, T. II, $1^{\mathrm{a}}$ Edición, Santiago: Editorial Jurídica de Chile, 1968.

GARCÍA, Octavio, "El delito de sustracción de menores y su configuración", InDret $\mathrm{N}^{\circ} 4$ (2010), disponible en: http://www.indret.com/pdf/767_es.pdf [visitado el 28.05.2015].

GARRIDO, Mario, Derecho Penal, T. III, $4^{\text {a }}$ Edición, Santiago: Editorial Jurídica de Chile, 2005-2010.

HERMOSILLA, Nurieldín, Sustracción de Menores, Ensayo de una interpretación dogmática del artículo 142, Memoria de Prueba para optar al grado académico de Licenciado en Ciencias Jurídicas y Sociales de la Universidad de Chile, Santiago: Editorial Universitaria, 1963.

LABATUT, Gustavo, Derecho Penal, Parte Especial, V. II, $7^{\text {a }}$ Edición, Santiago: Editorial Jurídica de Chile, 1983.

MUÑOZ CONDE, Francisco, Derecho Penal, Parte Especial, 5a Edición, Sevilla: Publicaciones de la Universidad de Sevilla, 1983. , Derecho Penal, Parte Especial, 17 Edición, Valencia: Tirant lo Blanch, 2009.

OLIVER, Guillermo, "Acerca de la retención de las víctimas en la comisión de un delito de robo con violencia o intimidación en las personas. A propósito de un caso real. Comentario a la sentencia del Tribunal de Juicio Oral en lo Penal de Quillota de 22 de agosto de 2007, RIT 35-2007”, Política Criminal № 4 (2007), pp. 1 a 16, disponible en http://www.politicacriminal.cl/n_04/d_6_4.pdf [visitado el 14.07.2015].

PACHECO, Joaquín, El Código Penal Concordado y Comentado, reedición de la tercera edición de 1867, Madrid: Edisofer, 2000.

POLITOFF, Sergio; MATUS, Jean Pierre; RAMÍREZ, María Cecilia, Lecciones de Derecho Penal Chileno, Parte Especial, $2^{\text {a }}$ Edición, Santiago: Editorial Jurídica de Chile, 2006.

QUINTANO RIPOLLÉS, Antonio, Tratado de la Parte Especial del Derecho Penal, T. I, V. II, $2^{\text {a }}$ Edición, Madrid: Editorial Revista de Derecho Privado, 1972. 
Polít. crim. Vol. 10, No 20 (Diciembre 2015), Art. 2, pp. 468-497.

[http://www.politicacriminal.cl/Vol_10/n_20/Vol10N20A2.pdf]

RODRIGUEZ DEVESA, José, Derecho Penal Español, Parte Especial, 9a Edición, Madrid: Artes Gráficas Carasa, 1983.

ROXIN, Claus, Derecho Penal, Parte General, T. I, Trad. LUZON PEÑA, Diego Manuel; DÍAZ Y GARCÍA, Miguel; DE VICENTE, Javier, Madrid: Civitas, 1997.

SAN MARTÍN, María Angélica, "Sustracción de Menores, Tipo Penal susceptible de ser cometido por uno de los padres", (Comentario de Sentencia), Revista Jurídica del Ministerio Público $\mathrm{N}^{\circ} 37$ (2008), pp. 272 a 277.

SOLER, Sebastián, Derecho Penal Argentino, $4^{\text {a }}$ Edición, Buenos Aires: Editorial Tea, 1987.

ZENTENO, Julio, Modificaciones al Código Penal 1979 - 1983, Modificaciones Legales del Quinquenio 1979 - 1983, Santiago: Universidad de Chile, 1984.

\section{JURISPRUDENCIA CITADA}

Tercer Tribunal de Juicio Oral en lo Penal de Santiago, sentencia Rit 172-2007.

Sexto Tribunal de Juicio Oral en lo Penal de Santiago, sentencia Rit 120-2006.

Tribunal de Juicio Oral en lo Penal de Antofagasta, sentencias Rit 96-2005 y 175-2009.

Tribunal de Juicio Oral en lo Penal de Chillán, Sentencia Rit 37-2005.

Tribunal de Juicio Oral en lo Penal de Los Ángeles, sentencia Rit 12-2009.

Tribunal de Juicio Oral en lo Penal de Quillota, sentencia Rit 35-2007.

Iltma. Corte de Apelaciones de Santiago, sentencia Rol 27.440-2001.

Iltma. Corte de Apelaciones de Temuco, sentencia Rol 1.192-2008.

Iltma. Corte de Apelaciones de Punta Arenas, sentencia Rol 129-2007.

Excma. Corte Suprema, sentencia Rol 10-2008. 